\title{
Increasing Liability Premiums in Obstetrics - Analysis, Effects and Options
}

\author{
Steigende Haftpflichtprämien in der Geburtshilfe - \\ Analyse, Auswirkungen und Optionen
}

Authors

Affiliations
P. Soergel ${ }^{1}$, O. Schöffski ${ }^{2}$, P. Hillemanns ${ }^{1}$, U. Hille-Betz ${ }^{1}$, S. Kundu ${ }^{1}$

Department of Gynaecology and Obstetrics, Hanover Medical School, Hanover. Abteilung für Gynäkologie und Geburtshilfe, Medizinischen Hochscule Hannover

${ }^{2}$ Chair of Health Management, Erlangen-Nürnberg University, Nuremberg

Key words
delivery
obstetrics
liability
Schlüsselwörter
Geburt
Geburtshilfe
Haftpflicht

Deutschsprachige Zusatzinformationen online abrufbar unter: www.thieme-connect.de/ ejournals/toc/gebfra

\section{received 17.2.2015 \\ revised $\quad 5.3 .2015$ \\ accepted 6.3.2015}

Bibliography

DoI http://dx.doi.org/ 10.1055/s-0035-1545955

Geburtsh Frauenheilk 2015; 75 : 367-376 @ Georg Thieme

Verlag KG Stuttgart · New York ISSN 0016-5751

\section{Correspondence}

PD Dr. Philipp Soergel, MHBA

Hannover Medical School

Department of Gynaecology

and Obstetrics

Carl-Neuberg-Straße 1

30625 Hannover

Soergel.Philipp@

mh-hannover.de

\section{Abstract \\ $\nabla$}

Whenever people act, mistakes are made. In Germany, it is thought that a total of 40000 cases of malpractice occur per year. In recent years, costs for liability insurance have risen significantly in almost all spheres of medicine as a whole. Liability in the health care sector is founded on the contractual relationship between doctor and patient. Most recently, case law developed over many years has been codified with the Patients' Rights Act. In obstetrics, the focus of liability law is on brain damage caused by hypoxia or ischemia as a result of management errors during birth. The costs per claim are made up of various components together with different shares of damage costs (increased needs, in particular therapy costs and nursing fees, acquisition damage, treatment costs, compensation). In obstetrics in particular, recent focus has been on massively increased liability payments, also accompanied by higher liability premiums. This causes considerable financial burdens on hospitals as well as on midwives and attending physicians. The premiums are so high, especially for midwives and attending physicians, that professional practice becomes uneconomical in some cases. In recent years, these circumstances have also been intensely debated in the public sphere and in politics. However, the focus here is on the occupation of midwife. In 2014, in the GKV-FQWG (Statutory Health Insurance - Quality and Further Development Act), a subsidy towards the occupational liability premium was defined for midwives who only attended a few deliveries. However, to date, a complete solution to the problem has not been found. A birth will never be a fully controllable risk, but in rare cases will always end with injury to the child. The goal must be to minimise this risk, through good education and continuous training, as well as constant critical analysis of one's own activities. Furthermore, it seems sensible, espe-

\section{Zusammenfassung \\ $\nabla$}

Wo Menschen handeln, werden Fehler gemacht. Insgesamt wird für Deutschland von 40000 Behandlungsfehlern pro Jahr ausgegangen. In den letzten Jahren sind die Aufwendungen für Haftpflichtversicherungen nahezu in der gesamten Medizin deutlich gestiegen. Die Haftung im Heilwesen wird durch die vertragliche Beziehung zwischen Arzt und Patient begründet. Zuletzt wurde jahrelang entwickeltes Richterrecht mit dem Patientenrechtegesetz kodifiziert. Im haftungsrechtlichen Mittelpunkt in der Geburtshilfe steht der hypoxisch-ischämische Hirnschaden durch Managementfehler unter der Geburt. Die Kosten pro Schadensfall setzen sich aus verschiedenen Komponenten zusammen mit unterschiedlichen Anteilen am Schadensaufwand (vermehrte Bedürfnisse, insbes. Therapie- und Pflegekosten, Erwerbsschaden, Heilbehandlungskosten, Schmerzensgeld). Insbesondere in der Geburtshilfe stehen die massiv angestiegenen Haftpflichtzahlungen und damit auch die Haftpflichtprämien in letzter Zeit im Fokus. Dieses bedingt erhebliche finanzielle Belastungen sowohl für Kliniken als auch Hebammen und Belegärzte. Gerade für Hebammen und Belegärzte sind die Prämien so hoch, dass eine Berufsausübung teilweise unwirtschaftlich wird. In den letzten Jahren sind diese Umstände auch im öffentlichen Raum und in der Politik intensiv diskutiert worden. Der Fokus liegt hier allerdings auf der Hebammentätigkeit. Im GKV-FQWG wurde 2014 für Hebammen mit nur wenigen Geburten ein Zuschuss zur Berufshaftpflichtprämie festgelegt. Eine grundsätzliche Lösung des Problems ist allerdings bis heute nicht gefunden. Eine Geburt wird nie ein voll beherrschbares Risiko sein, sondern immer in seltenen Fällen mit einer Schädigung des Kindes enden. Ziel muss sein, dieses Risiko zu minimieren, durch gute Ausbildung und kontinuierliches Training sowie ständiges kritisches Hinterfragen der 
cially in non-clinical Obstetrics, to look at the current study data more closely. Among the many solutions which have been proposed, such as the development of quality management, risk management and prevention, better remuneration, a waiver on recourse claims by social insurance underwriters, a cap on damage costs of liability insurers, state liability, an indemnity fund, a system change to Medical Treatment Risk Insurance, as well as a discussion on whether or not it makes sense to use non-clinical obstetrics for the prevention of a further increase in premiums, not one stands out as being especially convincing. On the contrary, a meaningful coordination of various concepts should follow. What seems sensible is a higher remuneration per birth, taking into account the liability premiums as well as, in the medium term, the establishment of a liability fund which, from a certain limit upwards, steps in as liable third party.

\section{Introduction}

$\nabla$

Whenever people act, mistakes are made. In medicine, the spectrum of consequences varies between inconsequential mistakes and, on the other hand, severe lifelong disability or death.

In recent years, costs for liability insurance have risen significantly in almost all spheres of medicine as a whole. The reasons for this are varied and based on the current practice of medicine and jurisdiction, as well as on social changes.

Recently, the focus has in particular been on liability payments as well as on liability premiums in obstetrics. The premiums are so high, especially for midwives and attending physicians, that professional practice becomes uneconomical in some cases. In recent years, these circumstances have also been intensely debated in the public sphere and in politics. However, the focus here is on the occupation of the midwife. However, to date, a complete solution to the problem has not been found.

This paper will analyse the extent to which the various stakeholders are concerned, what the causes of the increasing liability problems could be, what effects premium increases have, what effects these have on obstetrics in Germany and what potential solutions exist.

\section{Liability and Liability Insurance in Health Care $\nabla$}

\section{Malpractice}

The doctor has a duty of care to the patient "in accordance with the generally approved technical standards existing at the time of the treatment" ( $\$ 630$ a of the German Civil Code). If this is contravened, a case of malpractice exists. As a rule, the applicable standard is determined by what is known as the medical specialist standard. According to Carstensen, the "standard in medicine [...] represents the current status of scientific knowledge and medical experience which are necessary to attain the medical treatment goal and which have been proven in testing." [1]. In practice, this is decided by determining whether a treatment corresponded to the applicable medical standard, in regular consultation with expert medical opinion. In medical law, it is often the case that the patient can neither prove that a certain injury was caused by a certain mistake, nor can the doctor prove that the opposite is the case. Thus, it is the provision of evidence which represents the core problem in the medical liability process [2]. eigenen Tätigkeit. Es erscheint weiterhin sinnvoll, insbesondere die außerklinische Geburtshilfe aufgrund der Studienlage hier näher zu betrachten. Unter den vielen vorgestellten Lösungsansätzen wie dem Ausbau von Qualitätsmanagement, Risikomanagement und Prävention, einer besseren Vergütung, einem Verzicht auf Regressforderungen durch Sozialversicherungsträger, Deckelung des Schadensaufwands des Haftpflichtversicherers, Staatshaftung, eines Haftungsfreistellungsfonds, eines Systemwechsels zur Heilbehandlungsrisikoversicherung sowie einer Diskussion über Sinn und Unsinn außerklinischer Geburtshilfe zur Verhinderung eines weiteren Anstiegs der Prämien scheint keiner als herausragend überzeugend. Vielmehr sollte eine sinnvolle Abstimmung verschiedener Ansätze erfolgen. Eine höhere Vergütung pro Geburt unter Berücksichtigung der Haftpflichtprämien sowie mittelfristig die Einrichtung eines Haftungsfonds, der ab einer bestimmten Grenze als Dritthafter eintritt, erscheint sinnvoll.

Generally, a clear information gap exists between doctor and patient in medical liability processes. This leads to the fact that the above-mentioned provision of evidence is so complicated for the patient that, initially, burden of proof reliefs were introduced by jurisdiction. In 2013, by the introduction of the Patients' Rights Act, the decision-making section of the Medical Malpractice Chamber was codified and eight new articles were created especially as part of the treatment contract. In particular, inter alia, the following burden of proof reliefs were legally established on the patient's side ( $\S 630$ of the German Civil Code)

- Documentation: The doctor is obliged to document the treatment. The non-documentation of an essential measure indicates failure to carry out the measure.

- Fully controllable risks: In the case of faulty medical technical equipment or defective organisation, for example, malpractice is assumed. An example of this is forgetting to apply a dressing to the abdomen.

- Gross malpractice: In the case of a contravention of established medical knowledge by an error which does not appear understandable because it is absolutely unacceptable to a doctor, there is a burden of proof reversal. The doctor must now prove that the error did not lead to the patient's injury.

- Duty to inform: The doctor has the duty of proving that he/she has made the patient adequately aware of what is happening.

\section{Medical liability insurance}

Medical liability insurance insures medical activities. Apart from doctors, midwives especially are among the health care professionals who run a high risk of causing personal injury.

A specific feature of medical liability, particularly in obstetrics, consists of the fact that many injuries are only reported and regulated after a long time [2]. This is also called late liability, late damage risk or "Longtail effect of medical liability" and complicates the calculation of the provisions for damages and therefore also that of premiums [3]. In cases which are reported late, which are often also very expensive, there is always the danger to the insurer that the original premium calculation does not transpire to be fair cover.

In a survey by the German Physicians' Insurance (Deutsche Ärzteversicherung), the average doctor makes use of his medical liability insurance only once in 28 years [4]. The regulation quota, which describes the relationship of reported to settled damages, 


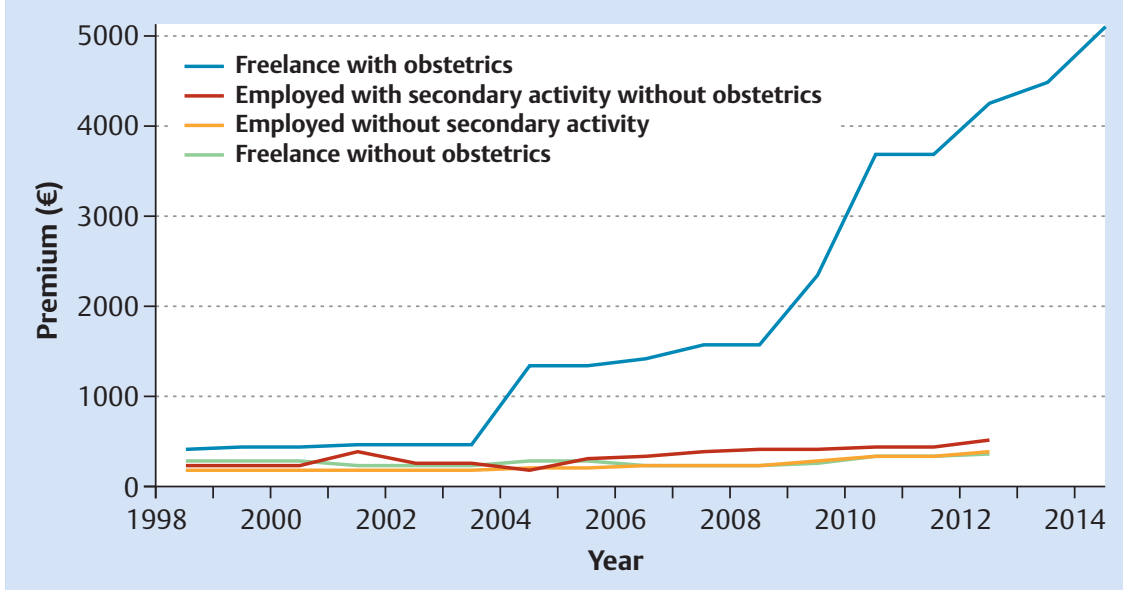

Fig. 1 Premium development for the occupation of midwife. Data from [14] and from Securon insurance brokers.

is constantly at approximately $30 \%$ in the medical field [5]. Currently, medical liability is in deficit overall with most insurers.

\section{Development and Current Situation in Obstetrics}

In obstetrics, the focus of liability law is on brain damage caused by hypoxia or ischemia as a result of management errors during birth.

There are no reliable data on the number of medical errors which occur in obstetrics. However, the damage frequency in obstetrics is placed lowest in the rankings in comparison to other disciplines. According to a study by Harvard Medical School, undesirable events occurred in $1.5 \%$ of obstetric patients, whereof negligent behaviour occurred in $38 \%$ of these cases, which leads to a malpractice rate of $0.57 \%$ [6,7]. In the medical field overall, the malpractice rate was higher, at 1.02\%. 673544 live births in Germany in 2012 led to approximately 3839 medical errors; the number of errors leading to miscarriage or stillbirth would also have to be added to this. $9.8 \%$ of medical errors in the delivery room led to a severe disability; projected on the living births in 2012 in Germany, this would mean approximately 376 cases per year. It is unclear to what extent the figures have improved thanks to better management in obstetrics since the publication of the study in 1991.

Conversely to damage frequency, damage costs in obstetrics are ranked in first place [8]. According to statistics from the GDV (German Insurance Association), costs for serious birth defects between 2003 and 2012 increased by approximately 7\% per year to an average of $€ 2.6 \mathrm{~m}$. Of increasing significance here are costs of increased therapy and care, as well as compensation for the loss of earnings of the injured child.

There are thus relatively few cases, but the damages caused are particularly demanding. Half of all the major damages in the total medical field are obstetric cases [5]. At Ecclesia GmbH, 65 of the 100 most costly claims ever were in the area of obstetrics [3]. At Deutsche Ärzteversicherung, 47 major claims of over $€ 200000$ in obstetrics represent $8.2 \%$ of cases, but constitute $84 \%$ of the financial costs [8]. In the case of midwives, $90 \%$ of the total sum of damages is expended on major claims of over $€ 100000$ [9].

On account of medical advances and, with these, increased life expectancy of the severely injured, the winding-up period increases, leading to a longer burden on the insurer of approx.
$€ 15000-25000$ per month [3]. This complicates the calculability of damages and thereby also that of premiums.

\section{Composition and development of damage}

The compensation must be calculated so that, if possible, the damage is eliminated, can be offset or relieved (e.g. costs for aftercare, pension, loss of earnings).

At present, the average birth defect results in costs of $€ 2.6 \mathrm{~m}$ [3]. The biggest known damage to date is a birth defect from a hospital with a cost of nearly $€ 15 \mathrm{~m}$ [10]. Increases during recent years mean that a vast number of insurers must accept winding-up losses in this sector.

The costs per claim are made up of various components, together with different shares of damage costs (increased needs, in particular therapy costs and nursing fees $35-45 \%$, acquisition damage $10-15 \%$, treatment costs $20-30 \%$, compensation 16\%) [10].

In particular, costs for increased needs are sharply rising - this includes, in addition to nursing services, physiotherapy, occupational therapy and speech therapy and medical services. The longer duration on account of increased life expectancy contributes to the remainder of the increase. Furthermore, in recent years, the average compensation has risen continuously by about $3.6 \%$ per year (from $€ 240000$ to $€ 290000$ between 1995-1998 and 2000-2003); however, in the meantime, these figures have also already probably been exceeded, because compensation amounts of up to $€ 500000$ have become due for serious birth defects [10].

\section{Situation for hospital as "Vollanstalt" (full institution)}

In general, no compulsory insurance exists for hospitals. However, most hospitals hold suitable policies. Only some large clinics consciously go without liability insurance [3]. However, this constitutes a certain risk, because nowadays, in the case of clinics which perform obstetrics, insurers work with insured sums of $€ 15-20 \mathrm{~m}$ [2]. One can imagine, for example, what would happen if, by coincidence, a large medical centre had two claims of over $€ 10 \mathrm{~m}$ in each case which needed to be settled in the same year. In an obstetric clinic as a full institution with appointed doctors and midwives, these are all insured as a rule by the clinic's liability insurance.

Until the end of the 1990s, the cost factor for liability insurances for hospitals made up only a minimal part of the total expenses at less than $1 \%$ [11]. In the meantime, about $€ 520 \mathrm{~m}$ per year is ex- 
pended throughout Germany on the liability premiums of hospitals, an increase of $+550 \%$ in comparison to 1991 ( $€ 80 \mathrm{~m}$ ) [2,12]. For the liability insurance of a hospital, in general an overall costing is done for the whole clinic, without any obstetrics department which may be present specifically being individually named. This is why an assessment of the liability costs for obstetrics at hospitals is difficult.

The most common method of premium calculation is still represented by what is known as the Bed Premium, which, according to the hospital risk structure, has recently reached $€ 800-1000$ per bed [11]. With a premium of $€ 100-200$ in 2003, this premium has risen by a factor of $4-10$ in 10 years. At present there is only one oligopoly of six supra-regional insurers for hospitals.

\section{Situation for attending physicians}

According to $\S 21$ of the Model Professional Code of Conduct (Musterberufsordnung), doctors are obliged "to insure themselves against liability claims within the scope of their professional duties". In this respect, in contrast to hospitals, an attending physician's duties are not possible without liability insurance. Precise figures do not exist regarding the number of attending physicians practising obstetrics in Germany. According to the data of the Professional Association of Gynaecologists (Berufsverband der Frauenärzte), the great majority of attending physicians have group insurance with $\mathrm{R}+\mathrm{V}$ Insurance, as well as Assekuranz AG [13]. In 2009, there were 389 contracts in this group contract, however, at the beginning of 2014, only 90 still existed. As is the case for midwives, it is difficult to become newly insured at all. The reason for this is the increasingly uneconomical nature of attending physicians' obstetric duties in the context of a decreasing birth rate on the one hand, at the same time, however, as constantly increasing liability premiums. Therefore, according to the Professional Association of Gynaecologists (Berufsverband der Frauenärzte) and the German Physicians' Insurance (Deutsche Ärzteversicherung), an attending physician without pre-existing damages must nowadays raise more than $€ 40000$ per year for obstetric liability $[8,13]$. Because an in-patient delivery without complications is remunerated at a rate of $€ 206$, this activity can generally only be profitable with a high number.

\section{Situation for midwives}

Midwives are particularly affected by the increase in liability premiums, because here the major claims affect a very small group. Moreover, the earning potential of midwives is limited.

A total of approximately 21000 midwives are active in Germany [14]. According to data from the German Insurance Association (Gesamtverband der Deutschen Versicherungswirtschaft), approximately 16000 freelance midwives have professional liability insurance, of whom about $25 \%$ perform obstetrics (in the in-patient midwife model (Belegmodell), in birthing centres or home births) and are confronted by sharply increasing premiums [9]. Therefore, with a collective of insured persons of only approx. 4000 , only a small market exists. About $20 \%$ of the active freelance midwives offer home birth services, and they perform 6 home deliveries per year on average ( 0.5 per month) [14].

The remuneration for a freelance delivery is $€ 275.22-342.17$ for a freelance midwife in a hospital, $€ 559.00-663.98$ for a birthing centre delivery and $€ 703.08-826.29$ for a home birth (independent of day and time).

According to the GDV (German Insurance Association) data, there are an average of approx. 8 damages per 1000 midwives per year [14]. The total damage costs are determined here decisively by the major claims. More than 30 insurers have midwives on their books, but only a few accept new midwives with freelance obstetric duties for professional liability. Most midwives are insured by group contracts of midwifery associations with a syndicate from the Bavarian Chamber of Insurance (Bayrische Versicherungskammer), $\mathrm{R}+\mathrm{V}$ Insurance, as well as Nuremberg Insurance (Nürnberger Versicherung).

In 2013, the premiums for freelance midwives with obstetric duties without pre-existing damages had already reached over $€ 4000$ [15] (O Fig. 1). Effective on 1st July 2014, the premium was again increased to $€ 5091$ per year. This means that a premium increase of approx. 117\% has taken place during the past 5 years. These premium increases are not covered by higher remuneration for obstetrics. If a home birth midwife performs 10 deliveries per year, liability costs of $€ 509$ per birth arise for her, from the proceeds of about $€ 703.08-826.29$ per birth. This cannot be economical on a long-term basis.

The provision of midwives' assistance, in particular their remuneration and insurance, has recently been the subject of intense public discussion.

In the GKV-Versorgungsstrukturgesetz (Statutory Health Insurance - Health Care Act) (GKV-VStG), it was determined for the first time that the increase in liability premiums is to be considered in negotiations on remuneration with organisations bearing the costs. However, according to midwifery associations, this regulation has to date not led to a significant relief, inter alia on account of the non-binding nature of the wording [15].

In 2014 in the "Act on the advancement of the financial structure and quality in legal health insurance" (GKV-FQWG - Statutory Health Insurance - Quality and Further Development Act), the demand was agreed for midwives with only a few births with the GKV National Association of Statutory Health Insurance Funds on the payment of a subsidy towards the professional liability premium. A permanent insurance surcharge is then to be agreed upon, which will be effective from 1st July 2015. Furthermore, minimum requirements will be defined for midwives with regard to structural quality, process quality and quality of results.

\section{Causes}

$\nabla$

There have always been and will always be birth defects, because birth will remain an especially risky moment in life. The causes of the current increase in sums for damages and therefore also of premiums are multifactorial.

Among the causes of the extent and development of liability premiums, the social factors which are, among other things, based on the wishes/demands of patients, must be distinguished from the legal and medical factors. Medical factors can be further subdivided into factors which cause an increased probability of damage as well as an influence on the damage severity, as well as factors which influence the sum of damages after occurrence of the damage.

\section{Social factors}

From misfortune to injustice

Increasing medical progress creates the feeling, particularly in obstetric patients, that the ancient event of birth with once fateful consequences has developed into a fully controllable risk today. Then disappointment rapidly spreads concerning the often clear current expectations. 
Püster explains that society sees damage less and less frequently as misfortune, but as needing to be balanced out; misfortune to be accepted is reinterpreted as an injustice giving rise to liability [2]. This probably applies; in the end, however, the patient has fortunately - the right to require reparation for an injury caused by malpractice. Faulty claims are often filed by a patient if, among other things, they perceive there to be blame for unfulfilled treatment success or an undesired outcome in spite of the perfect medical services of the doctor (or midwife) [2].

\section{From demigod in white and wise woman}

to health service provider

In recent years, the role of the doctor has increasingly altered from a paternalistic decision-maker towards a healthcare service provider, who encounters self-determining patients on an equal footing. This also applies to the profession of midwife.

The increasing strengthening of the self-determination of the informed patient, however, in return provides for a weakening of the trust relationship, thus non-recovery can possibly be regarded as the inadequate fulfilment of a contract by the doctor (or midwife). Additional annoyance occurs if couples demand "optimum" care at all times (e.g. lack of understanding that an anaesthetist must be waited for on the PDA system, demand for 1:1-midwife care), the SGB V (German Social Code - Book V), however, merely defines adequate, suitable care which does not exceed what is necessary, to which also the remuneration and, finally, also the allocation of staff are adapted.

\section{Media attention}

Through the Patients' Rights Act, as a result of fears of some insurers due to increased media attention, even more claims could be filed [11].

By the further omnipresent, predominantly negative, partly sensational reports of "malpractice" and "doctors' botch-up", the feeling has been evoked of being surrounded by quacks, which further damages the trust relationship between doctor and patient.

\section{Legal factors}

\section{Patient-friendly jurisdiction}

Jurisdiction, upon expert medical advice, has clearly tightened the behavioural obligations of doctors and midwives in recent years. Case Law, developed over decades, was further codified in 2013 by changes in the Patients' Rights Act and therewith eight new articles were especially created in the Treatment Contract ( $\$ \S 630 \mathrm{a}-\mathrm{h}$ of the German Civil Code). An unsuccessful or incorrectly executed or documented informing of the patient by the doctor can become the gateway for the opposing party to bring a case. The documentation of a birth in a way which is seen as brief by some and as sloppy by others, can lead to a burden of proof reversal, with considerable deterioration of the chances of averting a conviction. This leads to the fact that the corridor of what is demanded from a legal point of view and what is reasonable from a medical point of view has become exceptionally narrow in some situations.

\section{Components of acquisition damage}

With only a low life expectancy after severe birth defects, this item used not to be taken into consideration [2]. Today, however - with increased life expectancy of the severely injured - this is included virtually as a rule in the calculation of compensation.
According to Hellberg, costs of the Acquisition Damage component are increasing by almost $18 \%$ annually [10].

\section{Increase in awarded damages as non-material damage} Between 1995-1998 and 2000-2003, compensation awarded increased from an average of $€ 240000$ to $€ 290000$ - today, however, sums of up to $€ 500000$ are paid out in practice for severe birth defects [10]. According to Püster, the dramatic increase in compensation amounts is due to, inter alia, 2 judgements by the BGH (German Federal Court of Justice), which demanded a special calculation of the compensation in the cases of the most severe brain damage on account of the special value of personality and dignity of the person [2].

\section{Increase in recourse claims in the health service} by social insurance underwriters

Currently, damage is more and more often asserted not by the injured person, but systematically by the organisation bearing the cost of the injured person as a so-called recourse [11]. As a rule, these are statutory or private health insurance schemes as well as pension insurance institutes. According to data from the German Insurance Association (Gesamtverband der Deutschen Versicherungswirtschaft), the proportion of these reclaims constitutes $25 \%$ of the total sum of claims in major personal damages [9]. Today, nearly all health insurance schemes accordingly have trained Recourse Departments.

Basically, recourse should not just be valued negatively, because it should of course already be the case that - like in all Indemnity Law - the person responsible bears the damage and not the supportive community. The imbalance results from the fact that insurers have not taken into consideration these costs in recent years in provisional calculations.

\section{Influence of the risk of a birth defect and its severity} Even with the best education and organisation, every birth presents a risk situation for the mother, but in particular for the child.

\section{Change in the pregnant collective}

Increasingly, people in Germany tend to postpone fulfilling their wish to have children more and more. This leads to older pregnant women and an increased rate of high-risk births. The average age at the birth of the 1 st child rose from 24 years in 1970 to 29 years in 2012, according to the Federal Statistical Office. Thus we can see from the data of the AQUA Institute that in 2013, $76.3 \%$ of all pregnant women exhibited at least one pregnancy risk and $77.9 \%$ exhibited a birth risk [16].

Furthermore, the Caesarean section rate is also increasing. In 2013, 33.4\% of all deliveries were by Caesarean section (219863 C-sections) [16]. In particular, this also leads to an increased risk in further births for these women. The risk also increases due to the increase in reproductive medicine.

This does not necessarily mean, of course, that liability premiums must increase. However, more complex pregnancies and births also present a higher risk of error for attending medical staff (increase of error probability), and mistakes possibly also have more severe consequences if the population is older and more sickly (increase in consequences of the error).

\section{Non-clinical obstetrics}

In Germany, over $98.5 \%$ of births take place in hospitals [17]. This means that $1.5 \%$ take place outside hospital. 
The safety of non-clinical obstetrics, which include birthing centre deliveries, home births as well as a few unplanned births, is continuously being discussed and questioned [18]. The advocates of home birth argue with regard to "patient safety, cost savings, contentment and respect for patients' wishes". The advocates of hospital births, meanwhile, cite the maximum safety which exists only in a clinic, and a reminder of the interest of the child to survive the birth unharmed [18].

There are many studies which compare the results of non-clinical obstetrics with those of clinical obstetrics, however only a few are of very good quality. A significant analysis was published in 2014 in the USA [19]. In an evaluation of 13.9 million births, it was found that the risk of neonatal death (within 4 weeks after birth) is increased by $287 \%$ in a home birth in contrast to a clinic birth. For first-time mothers or women over the expected date of delivery, an even greater increase in risk by 574 or $576 \%$ is shown. This means that for the increased mortality, the following must be taken into account: If 10000 women choose a midwife home birth instead of a midwife clinic birth, statistically speaking, 9.3 more children will die [19].

Other large meta-analyses deliver similar results [20]. It is to be pointed out that in this case, only neonatal mortality was analysed. Children who survive, but who are severely disabled, are not recorded here. In a further investigation of these 13.9 million births, the number of cases of neurological abnormalities and/or cerebral seizures was examined as a parameter of brain damage [21]. It appeared that the risk was increased 3.8-fold in a home birth in comparison to a hospital birth, in a first-time mother even by a factor of 6.3. Also in births in birthing centres not connected to clinics, the risk was increased 1.9-fold or 2.8-fold [21].

In Germany there are data from the Society for Quality in nonclinical Obstetrics (Gesellschaft für Qualität in der außerklinischen Geburtshilfe e.V.) which records childbirth parameters on a voluntary basis. For 2012 , perinatal mortality of $1.8 \%$ is recorded [17], a little higher than the neonatal morbidity in the above-mentioned American study. However, the capture rate in recent years has only been between 80 and 90\% [17]. In this respect, there is no guarantee that, in particular, all pathological birth processes with undesirable outcomes for the parties involved are entered in the statistics. For example, in an ongoing criminal process against a midwife, it transpired that several perinatal deaths had not been registered.

In the course of a non-clinical birth, transfer often takes place to a clinic with an obstetrics department. In the literature, for firsttime mothers the transfer rate given is high at 36-49\% (Germany: $31 \%)[17,22,23]$. For multiparous women, the rate is $9-17 \%[22$, 23]. This shows that, among other things, the distance which must be covered to the clinic plays a big role in an emergency situation. In the clinic, for many years it has been standard practice that, in an emergency situation for the child or the mother, a delivery - for example, an emergency Caesarean section - should be carried out as fast as possible, in any case, however, within a time frame of $<20-30$ minutes between decision and delivery [2426]. This can hardly ever or never be achieved if time factors are taken into consideration, such as requirement of a life-saving device, loading, journey, unloading, etc. Hence, the acceptance of the described risks is considered overall by many experts to be ethically unacceptable and, hence, a delivery in a clinic is recommended [18,27].

A factor not to be neglected is also the fact that, in a good hospital delivery room, a multiprofessional team mostly composed of several midwives and doctors cares for a woman in confinement, while in a home birth, for example, a midwife is alone. In the clinic many different opinions and assessments are expressed - this also has disadvantages and may be stressful, however, it has the advantage that, for example, a decision on the course of a delivery or a CTG is made by several persons - which decreases the risk that, from a kind of blinkered attitude, a much-desired - but only to be realised under high risk - course of delivery is adhered to, although clinically already clear pathological signs are present. Due to concerns about the health of mother and child, the Professional Association of Gynaecologists (Berufsverband der Frauenärzte) recommends delivery in a clinic [28]. The German Society of Gynaecology and Obstetrics (Deutsche Gesellschaft für Gynäkologie und Geburtshilfe) also recommends that no home births be carried out [29]. In the Editorial of The Lancet, this view was summed up briefly and to the point in 2010: "Women have the right to choose how and where to give birth, but they do not have the right to put their baby at risk." [30]

\section{Increase in sums for damages through medical factors} Factors to be named for the increase in the total sums for damages are the increased life expectancy of the severely injured and improved therapeutic and care possibilities. Through better neonatal care, children who just a few years ago would have died, instead survive (severely disabled).

\section{Increasing life expectancy of the severely injured}

Today, on account of the advances in modern medicine, the severely injured have a considerably increased life expectancy since the beginning of the 1990s. This increased life expectancy means that a paid pension is covered for a longer period, as well as also resulting in increased care costs.

\section{Improved therapeutic and care possibilities}

In the current jurisdiction, compensation is calculated as a rule so that home care is possible by professional staff [10]. As well as nursing services, this also includes physiotherapy, occupational therapy and speech therapy and medical services. Also in this respect, medicine has steadily advanced in recent decades and can offer more and better services. Therefore, besides the mere eligibility period of the services, also the quality of the care and with it also the costs increase. This may be the reason why, according to data of the German Insurance Association (Gesamtverband der Versicherungswirtschaft), the costs for so-called "increased needs", are rising by approximately $14 \%$ per year [10].

\section{Effects}

\section{Effects on service providers}

Cost pressure necessarily leads to a concentration on larger centres. This seems sensible to a certain extent, because it is questionable how well emergency competencies, for example, can be trained in obstetric teams, if in a small private hospital only 100 births take place per year. According to Feige, in the whole of the UK with 60 million inhabitants, hospital obstetrics is practised in about 60 locations, whereas in Germany with 80 million inhabitants, obstetrics is available in 900 locations [31]. In many rural regions, clinical obstetrics is carried out by attending doctors. If liability premiums, inter alia, increase, the exercising of this professional practice - in particular with a low number of births - becomes uneconomical. Thus, within the space of a few years, the number of authorised gynaecologists who offer 
obstetrics has decreased nationwide from 17800 to 13300 . Meanwhile, in some rural districts there is no longer any hospital obstetric department.

However, there are also other opinions on this subject: Experts state, for example, that by closing smaller clinics with low birth rates, the quality of obstetrics increases because, from a professional perspective, a concentration of high birth rate departments with well qualified and continuously trained teams makes perfect sense [32]. The question therefore arises as to the extent to which this emerging centring of obstetric care also corresponds to the political will. Some researchers firmly demand that politicians should be convinced to plan bigger obstetric units for the increased safety of mother and child [18].

Fewer and fewer midwives are offering freelance obstetrics. Between 2008 and 2010, for example, their share decreased from 25 to $21 \%$ [14]. The primary cause for this is given as the lack of profitability on account of the massively increased liability premiums.

The decrease in the number of obstetric departments also has huge effects on non-clinical obstetrics. For example, if the only obstetric department in the vicinity of $30-40 \mathrm{~km}$ is closed, then no birthing centre in this location can offer meaningful safe obstetrics any longer, because a quick transfer is impossible in an emergency.

\section{Defensive medicine}

Defensive medicine consists of carrying out overdiagnosis for purely legal reasons, or of omitting a presumably more high-risk therapy [33]. In the field of obstetrics this is of particular significance. The increasing Caesarean section rate in Germany is certainly caused by - besides other things - a defensive medical component.

\section{Possible Solutions}

$\nabla$

The discussion mentions numerous solution options which begin with the cost bearers, the state or the service providers.

\section{Development of quality management,}

risk management and prevention

The establishment or improvement of quality management and/ or risk management is required of nearly all involved actors. Thus, mistakes should be learned from and repeating a similar course of damage be avoided. Methods for this include, above all, CIRS (critical incident reporting systems) and complaint management systems.

Before conclusion of the insurance, many liability insurers nowadays already request information about existing risk management systems, and with some insurers, audits are also held.

\section{Better remuneration taking into account \\ liability premiums}

In industry it is understood - not only in high-risk branches like the Chemical or Energy industries - that premium increases will be passed down to the prices [3]. In medicine, this is not possible so simply.

Petry reports that Ecclesia GmbH plans for $€ 300$ per birth in liability costs [3].

This relatively easy way could cushion premium increases. In this respect, doctors/clinics performing obstetrics, as well as midwives, would simply receive an accordingly higher remuneration as premiums increased. This path has already been trodden several times in the past for midwives [12]. The 2014 German Medical Assembly (der Deutsche Ärztetag) requests this as a shortterm solution for all professional groups [34].

\section{Restriction of or a waiver on recourse claims by social insurance underwriters}

The German Insurance Association (Gesamtverband der Deutschen Versicherungswirtschaft) and other authors among doctors and midwives demand a recourse waiver by social insurance underwriters, because this "[would] reduce claims expenditure by about 25\%, without reducing victim protection" [9]. The 2014 German Medical Assembly (der Deutsche Ärztetag) expressly supports this suggestion [34]. In addition, a limitation on the recourse would be a solution with only minimal bureaucratic cost. However, considerable legal reservations exist about this suggestion, inter alia, because this means that the basic principle that recourse is made to the perpetrator of the damage, is breached.

\section{Cap on damage costs of liability insurers}

In the discussion, a cap on the maximum damage to be settled is also mentioned repeatedly. Basically, several mechanisms are conceivable in this respect. Excess Insurance models are increasingly under discussion [11]. According to Petry, large private clinics are trying to keep the increase in premiums within a financially viable framework by doing this [3].

From an economic viewpoint, this offers the policyholder the advantage that a liquidity advantage is created, because first low premiums accrue, and deductibles, if applicable, appear only years later after possible claims. Provision must be made for this. One of the disadvantages is that there is a risk of an excessive financial demand due to a self-caused or possibly also purely incidental accumulation of major claims, in particular if no provisions are made, or they are made at unsuitable levels. The model is not suitable for freelance midwives on account of the very restricted earning potential and the high risk.

Another advantage of a deductible model which should be mentioned is a strengthened motivation to have adequate risk management and quality management [3].

\section{State liability}

In 2014, the German Medical Assembly (der Deutsche Ärztetag) suggested a birth defect regularisation by state liability which was analogous to the vaccination damage model [34]. For publicly recommended protective vaccinations, the state pays for care in the case of vaccine damage. The idea of the model is that, after the person who has caused damage reaches a deductible limit, the state should pay a lump-sum compensation.

A similar model is already being applied in France; severe birth defects which exceed the sum insured of the liability insurers are carried by the supportive community (collectivité nationale) [2].

\section{Indemnity fund and liability fund}

A fund-based solution, depending on the form, represents a liability-substituting or liability-supplementary solution. In this respect, the fund as a third-party debtor would become liable for payment from a certain limit upwards.

Several midwifery associations support the establishment of an Indemnity Fund or a Liability Fund [15]. According to the suggestion by midwifery associations, the money in such a fund should come from the GKV (Statutory Health Insurance) and also from 
the insurers, who would then further increase contributions - to a lesser extent.

Finally, these sums must also be carried, in addition to the capping amount, by contributions/taxes, this therefore involves a redistribution to make the risk for the primary insurer more calculable. A point of criticism is that it is unclear whether contributions would be lower if the pure organisational form of the liability taker were changed.

\section{System change to medical treatment risk insurance}

Medical Treatment Risk Insurance (or Patient Insurance) insures the patient against malpractice [33]. In some European countries (Scandinavian states and Austria), such a model is already enshrined in law. Püster suggests a design of a "Medical Accident Insurance" according to the model of statutory Accident Insurance [2]. In this case, patients would be insured against damages as a result of medical treatment, while damages from ordinary life risk as well as consequences of underlying diseases of the patient would be excluded. This differentiation will probably represent one of the biggest problems in practice [33]. The financing would be through contributions by doctors and other health practitioners [2].

An advantage would be that the doctor-patient relationship would be less negatively affected by a mistake, because the patient would not make a claim against the doctor, but against the insurer. A disadvantage would be that the financial costs would probably be at least equally as high. Because in this system the damage would be compensated for as an error as a result of treatment without proof of the causality, still higher costs would probably result. For example, if a patient suffers an intestinal injury during a Caesarean section on account of obesity of $195 \mathrm{~kg}$, this would then be settled - irrespective of fault - by the Medical Accident Insurance; however, it is actually difficult to explain why the health care profession should answer for the risk factors which are inherent in patients themselves. Furthermore, an undermining of the concept of prevention is to be feared with the discontinuation of possible personal liability of the doctor or his insurance $[2,33]$.

\section{Change in calculation basis of premiums}

Until now, an all-inclusive premium became due in the area of midwife liability insurance for freelance/in-patient obstetrics. One possibility would be to orient the premium amount more towards the number of deliveries performed. This would burden midwives with many deliveries, while significantly relieving midwives with only a few deliveries [15]. A point of criticism here is that in this case, no "minimum quantity" of deliveries must be carried out by a midwife any longer. Until now, with premiums of about $€ 4000$, most midwives in the non-clinical or in-patient fields have delivered a few babies fewer per year, because their insurance would otherwise have made their work extremely unprofitable. If one settles the insurance amount only according to the number of births per year, a midwife could carry out only 1-2 births per year - which certainly appears to be insufficient in order for the midwife to have the necessary routine - precisely in emergency situations.

Another possibility is to take the risk profile of a midwife into greater consideration: A freelance midwife in a Level I perinatal centre where neonatologists, specialists with "Special Obstetrics", and anaesthetists stand by 24 hours per day and 2000 deliveries may be performed per year, certainly has a totally different - reduced - risk for a disastrous case of damage than a home birth midwife - however, both are classified under the current premium system as a "freelance midwife with obstetrics" and must pay the same premium amount.

\section{Informing people honestly about the pros and cons of non-clinical obstetrics}

The present data unambiguously show that the risk of neonatal injury or peri- or neonatal death is significantly increased - in particular in home births (death: $+287 \%$, neurological damage: + 280\%) $[19,21]$. The risks for birthing centres are lower, but still significantly increased (death: $+162 \%$, neurological damage $+90 \%$ ). No German data are available which obligatorily record all non-clinical deliveries; the present voluntary data are similar to those of the American study.

In the IGES study, $11 \%$ of midwives with only non-clinical births attended only one complete delivery per year, another $22 \%$ between 2 and 5 births per year [14]. This appears to be absolutely insufficient to remain in training with regard to emergency situations.

Basically, the additionally accepted risks of a home birth can indeed be avoided - by delivery in a hospital. If the increased risk is considered alone, therefore, which is something well documented by studies (and also by the insurance premiums to be paid), then - purely from risk-reducing considerations - no home obstetrics should be carried out. Of course, the pregnant woman's right to self-determination has a very special value. For this reason, the decision on the place of birth basically should and must be left to her, even if this may be accompanied by a 4-fold increased rate of death and brain damage. What doctors and midwives should do is to honestly inform the woman about the advantages and disadvantages of different places for giving birth [31]. In this respect, an ideal, mystical exaggeration of a birth should not be described [35], but rather an honest explanation of the clinical data.

\section{Use of modern outcome parameters \\ in non-clinical obstetrics}

For the clinical postpartum assessment of the child, the Apgar is regularly considered, whereby the value after 5 minutes is particularly significant.

Nevertheless, Apgar values are susceptible to unintentional (or deliberate) manipulation. In a recently published study, Grünebaum showed that infants in home births have a 15-29-fold increased likelihood of being assigned the maximum value of 10 points after 5 minutes [36]. This is explicable not by the fact that these babies are really all in better health clinically, but by the fact that the non-clinical raised Apgar values are obviously distorted - in terms of being erroneously assigned as too good. This is of importance in respect of the fact that, in many studies, one of the parameters which should cover the safety of the non-clinical birth is the Apgar value after 5 minutes. In this respect, the judgement of these studies must be approached extremely carefully; which devalues in this respect, however, the message of these data that non-clinical obstetrics is just as safe as clinical.

The postpartum pH value is one of the most important quality parameters after a birth. In particular, oxygen deprivation during delivery can be ruled out by this method. In this respect, this value as an objectively measurable parameter also has some weight in medical liability processes. In the case of typical brain damage (spastic cerebral palsy) existing in a newborn, it is not necessarily likely with a normal birth $\mathrm{pH}$ that the damage originated during delivery [37]. This would mean, then, that in a medical liability 
process, together with the presentation of a non-remarkable CTG during birth, there is a higher probability that a liability could be averted.

In non-clinical obstetrics, neither is a pH determination carried out after the birth, nor are the heart sounds continuously monitored during the final phase of the birth. Moreover, midwives are naturally also not obliged to their standards in a non-clinical setting. However, in the event of legal proceedings, it is therefore not possible to provide quick and relatively conclusive evidence (by normal CTG and normal $\mathrm{pH}$ ) that, according to objective criteria, the infant did not suffer from postpartum oxygen deprivation. The midwife would not have to produce this proof at all, because the burden of proof lies here with the plaintiff - however, if on account of a lack of material documentation or any other reason for the burden of proof reversal, for example, the likelihood would not be minimal that the process would turn out to the disadvantage of the midwife. The authors believe that in a clinic, in case of the presence of a non-pathological CTG and normal pH, the chances would be better for the obstetric side. It should be noted, however, that the medical outcome for the child is precisely the same - only the liability risk would be different.

The determination of modern outcome parameters, such as the umbilical artery's pH, would also be possible in non-clinical obstetrics - at least in birthing centres. Today there are mobile, portable blood gas analysis devices - as for example already used on the intensive care transport trolley - with which a drop of umbilical cord blood could be examined directly after the birth. Because the measurement can be done quickly and without great cost, this would also not disturb the always particular atmosphere of the non-clinical birth, while nevertheless delivering a dependable and less susceptible outcome parameter for it. Among other things, this could relieve the midwife in the case of threatened liability processes; in the case of bad $\mathrm{pH}$ values, when appropriate, a quicker and targeted therapy could follow in the paediatric clinic. Fewer lost cases lead to lower premiums. In the long term, this also allows better quality assurance of non-clinical obstetrics.

\section{Summary and Outlook}

In general, it is assumed therefrom that "despite all measures, [...] from the current viewpoint, the premium development will not become more positive in future" [3]. Another increase in premiums is expected during the next 10 years.

A birth will never be a fully controllable risk, but in rare cases will always end with injury to the child. The goal must be to minimise this risk, by good education and continuous training, as well as a constant critical analysis of own activities. Furthermore, it seems sensible, especially in non-clinical obstetrics, to look at the current study data more closely. To be evaluated positively in this respect is the fact that, in the GKV-FQWG (Statutory Health Insurance - Quality and Further Development Act), the necessity for the minimum requirements of structural quality, process quality and the quality of results was enshrined in law for midwives too. Of the many solutions proposed, none appears outstandingly convincing. Instead, there should be a meaningful coordination of various approaches. A higher remuneration per birth, taking into account the liability premiums, as well as, in the medium term, the establishment of a Liability Fund which, from a certain limit, steps in as liable third party, seem most sensible. In the GKV-FQWG (Statutory Health Insurance - Quality and Further
Development Act), a higher remuneration in the form of a service guarantee surcharge was agreed for midwives. However, this is if an arrangement independent of the number of cases occurs as an all-inclusive amount - not to be assessed absolutely positively, because through this an incentive for minimum numbers ceases to exist. It is to be hoped that this is regulated by the called-for minimum quality requirements. A more specific premium calculation - in particular for freelance midwives separated according to in-patient, birthing centre and home birth activities - would better illustrate the further obstetric risk, indeed, concerning the price in each case again of smaller groups of insured persons. In addition to further good studies, a wide-ranging public discussion should follow on the advantages and in particular the disadvantages of non-clinical obstetrics.

\section{Conflict of Interest}

$\nabla$

None.

\section{References}

1 Carstensen G. Vom Heilversuch zum medizinischen Standard. Dtsch Ärztebl 1989; 86: A2431-A2433

2 Püster D. Entwicklungen der Arzthaftpflichtversicherung. Heidelberg: Springer; 2013

3 Petry M, Grabow J. Haftpflichtversicherung im Krankenhaus - quo vadis? Das Krankenhaus 2013; 6: 601-604

4 Flintrop J, Korzilius H. Arzthaftpflicht - Der Schutz wird teurer. Dtsch Ärztebl 2014; 107: A692-A694

5 Gaidzik P, Müller J, Tacke A. Risk-Management im Krankenhaus. In: Bergmann K, Kienzle H, Hrsg. Krankenhaushaftung. 3. Aufl. Düsseldorf: Deutsche Krankenhaus Verlagsgesellschaft mbH; 2010

6 Brennan TA, Leape LL, Laird NM et al. Incidence of adverse events and negligence in hospitalized patients. Results of the Harvard Medical Practice Study I. N Engl J Med 1991; 324: 370-376

7 Leape LL, Brennan TA, Laird $N$ et al. The nature of adverse events in hospitalized patients. Results of the Harvard Medical Practice Study II. N Engl J Med 1991; 324: 377-384

8 Schlösser G. Die Arzthaftpflichtversicherung - Daten, Fakten, Zahlen. MedR 2011; 29: 227-229

9 Gesamtverband der Deutschen Versicherungswirtschaft. V. Die Positionen der deutschen Versicherer, 2014. Online: www.gdv.de/wp-content/uploads/2014/04/GDV-Politische-Positionen_2014_nn.pdf; Stand: 18.07.2014

10 Hellberg $N$, Lonsing $M$. Komposit: Dramatische Teuerung von Personenschäden im Heilwesen. Versicherungswirtschaft 2010; 65: 421

11 Gaede K, Mau J. Prämienexplosion. Kma 2013; 3: 30-37

12 Rieser S. Hebammenvergütung: Zuschlag wegen höherer Haftpflichtprämien. Dtsch Ärztebl 2010; 107: 28-29

13 Hibbeler H. Haftpflichtprämien - Geburtshilfe in Gefahr. Dtsch Ärztebl 2014; 111: A490

14 IGES Institut. Versorgungs- und Vergütungssituation in der außerklinischen Hebammenhilfe, 2012. Online: http://bmg.bund.de/ fileadmin/dateien/Downloads/H/120504_IGES-Gutachten_ Versorgungs_und_Verguetungssituation_in_der_ausserklinischen_ Hebammenhilfe.pdf; Stand: 23.07.2014

15 BMG, Interministerielle Arbeitsgruppe „Versorgung mit Hebammenhilfe“. Abschlussbericht und Anlagen, 2014. Online: www.bmg.bund.de/fileadmin/dateien/Publikationen/Gesundheit/Bericht/Abschlussbericht_IMAG-Gesamt.pdf; Stand: 20.07.2014

16 AQUA-Institut. Bundesauswertung zum Erfassungsjahr 2013, Modul 16/1, Geburtshilfe, 2014. Online: www.sqg.de/downloads/Bundesauswertungen/2013/bu_Gesamt_16N1_GEBH_2013.pdf; Stand: 27.07.2014

17 Gesellschaft für Qualität in der außerklinischen Geburtshilfe. V. Qualitätsbericht 2012 - Außerklinische Geburtshilfe in Deutschland, 2013. Online: www.quag.de/downloads/QUAG_bericht2012.pdf; Stand: 27.07.2014 
18 Arabin B, Chervenak FA, McCullough LB. Die geplante Hausgeburt in industrialisierten Ländern: Bürokratische Traumvorstellung vs. professionelle Verantwortlichkeit. Z Geburtshilfe Neonatol 2013; 217: 7-13

19 Grünebaum A, McCullough LB, Sapra KJ et al. Early and total neonatal mortality in relation to birth setting in the United States, 2006-2009. Am J Obstet Gynecol 2014; 211: 390.e1-390.e7

20 Wax JR, Lucas FL, Lamont M et al. Maternal and newborn outcomes in planned home birth vs planned hospital births: a metaanalysis. Am J Obstet Gynecol 2010; 203: 243.e1-243.e8

21 Grünebaum A, McCullough LB, Sapra KJ et al. Apgar score of 0 at 5 minutes and neonatal seizures or serious neurologic dysfunction in relation to birth setting. Am J Obstet Gynecol 2013; 209: 323.e1-323.e6

22 Brocklehurst P, Hardy P, Hollowell J et al.; Birthplace in England Collaborative Group. Perinatal and maternal outcomes by planned place of birth for healthy women with low risk pregnancies: the Birthplace in England national prospective cohort study. Br Med J 2011; 343: d7400

23 Amelink-Verburg MP, Verloove-Vanhorick SP, Hakkenberg RM et al. Evaluation of 280,000 cases in Dutch midwifery practices: a descriptive study. BJOG 2008; 115: 570-578

24 American College Obstetrics and Gynecology. Committee Opinion no. 116. Practice Bulletin. Management of intrapartum fetalheart rate tracings. Obstet Gynecol 2010; 116: 1232-1240

25 Boehm FH. Decision to incision: time to reconsider. Am J Obstet Gynecol 2012; 206: 97-98

26 Deutsche Gesellschaft für Gynäkologie und Geburtshilfe. Mindestanforderungen an prozessuale, strukturelle und organisatorische Voraussetzungen für geburtshilfliche Abteilungen der Grund- und Regelversorgung. 2013. Online: http://www.awmf.org/uploads/tx_leitlinien/015078I_S1_Prozessule_Strukturelle_-Organisatorische Voraussetzungen_2013-05.pdf; Stand: 15.01.2015

27 Chervenak FA, McCullough LB, Arabin B. Obstetric ethics - an essential dimension of planned home birth. Obstet Gynecol 2011; 117: 11831187
28 Berufsverband der Frauenärzte. Die Geburt - die gefährlichste Stunde im Leben eines Menschen, 2013. Online: www.bvf.de/presse_info. php?r=2\&m=0\&s=0\&artid=440; Stand: 09.08.2014

29 Deutsche Gesellschaft für Gynäkologie und Geburtshilfe. Hausgeburt Risiken erhöht, 2011. Online: www.dggg.de/publikationen/stellungnahmen/?eID=dam_frontend_push\&docID=1566; Stand: 09.08.2014

30 Lancet Editorial. Home birth - proceed with caution. Lancet 2010; 376: 303

31 Feige A. Probleme der belegärztllichen Behandlung in der Geburtshilfe. In: Arbeitsgemeinschaft Rechtsanwälte im Medizinrecht e.V., Hrsg. 25 Jahre Arbeitsgemeinschaft - 25 Jahre Arzthaftung - Von der Krähentheorie zum groben Behandlungsfehler. Heidelberg: Springer; 2011: 55-62

32 Schleußner E, Stepan H. Geburtshilfe nicht gefährdet! Dtsch Ärztebl 2014; 111: B689-B690

33 Katzenmeier C. Arzthaftpflicht in der Krise - Entwicklungen, Perspektiven, Alternativen. MedR 2011; 29: 201-216

34 Bundesärztekammer. Beschlussprotokoll des 117. Deutschen Ärztetags, 2014. Online: www.bundesaerzte-kammer.de/downloads/117DAETBeschlussprotokoll20140613.pdf; Stand: 25.07.2014

35 Uphoff R. Aufklärung und Indikation zur Sectio als Beispiel für geburtshilflichen Paternalismus versus Geburtsmedizin als Dienstleistung für autonome Gebärende. In: Arbeitsgemeinschaft Rechtsanwälte im Medizinrecht e.V., Hrsg. 25 Jahre Arbeitsgemeinschaft - 25 Jahre Arzthaftung - Von der Krähentheorie zum groben Behandlungsfehler. Heidelberg: Springer; 2011: 287-307

36 Grünebaum A, McCullough LB, Brent RL et al. Justified skepticism about Apgar scoring in out-of-hospital birth settings. J Perinat Med 2014; DOI: $10.1515 / j p m-2014-0003$

37 American College Obstetrics and Gynecology. Committee Opinion no. 348. Umbilical cord blood gas and acid-base analysis. Obstet Gynecol 2006; 108: 1319-1322 